\title{
Means of Communication
}

\section{Transnational Struggles and Scarce Resources}

\author{
Thomas Hylland Eriksen
}

\begin{abstract}
Marx, famously, "placed Hegel on his feet" by arguing the primacy of economic and material processes over the spiritual and intellectual. In his analysis, the world advanced, dialectically, through growing contradictions between means of production and relations of production (property relations), mediated by recurrent class struggles. Although material scarcity is by no means absent from the contemporary world, an important scarce resource analysed well by Hegel and largely neglected by Marx, and which is essential today, is self-esteem, including the right to define oneself. Using examples from identity politics in a number of countries, I am trying to show that a democratisation of the means of communication may be a key to a less volatile world and an important dimension of a more equitable world society.
\end{abstract}

Keywords: postcolonialism, cosmopolitanism, communication, identity, globalisation, recognition

\section{Introduction}

It may sometimes appear as if the world is overfilled by humans and the products of their activities. A hundred years ago, the planet was inhabited by a grand total of 1.7 billion persons; global population now stands at more than 6.5 billion, and the percentage with their own Internet accounts, Facebook profiles and cellular telephones increases every year. No matter how one goes about measuring degrees of connectedness in the contemporary world, the only possible conclusion is that many more people today are much more connected than ever before in history. There are more of us, and each of us has, on average, more links to the outside world than our predecessors, through business travel, information, communication, migration, vacations, political engagement, trade, development assistance, exchange programmes and so on. The number of transatlantic telephone lines has grown phenomenally in the last few decades; so has the number of websites and international NGOs.

It can indeed be argued that this is a new world, which in significant ways differs from all epochs that preceded it. Most of us now live under the bright light of the powerful headlights of modernity, as genuine contemporaries, aware, however dimly, of one another. Lévi-Strauss bemoans the emergence of such a disenchanted world.

Among social theorists, a flurry of books, journals, articles and conferences have since around 1990 sought to re-define the human world - the post-cold war world, the postco- 
lonial world, the world of global modernity or the world of a deterritorialised information society - sometimes inventing new theoretical concepts, sometimes giving new tasks to old vocabulary (see Eriksen 2007 for an overview). A number of themes recur throughout this vivid and sometimes cacophonic discourse. I will mention a few initially.

The concept of the network. Established as a staple in studies of globalisation by at least two of the most prominent theorists in the field (Castells 1996 and Hannerz 1996), the concept of the network implies that stable hierarchies and structures are giving way to nodal, multicentred and fluid systems, and that this change takes place in numerous fields of interaction. (This concept should not be confused with the Actor Network Theory idea of the network developed by Bruno Latour, to which it is related: ANT networks include both human and non-human agents.) In Hardt and Negri's Empire (2000), which famously argues the fading away of territorial powers to the benefit of a jellyfish-like, omnipresent force that they call 'empire', the influence from Deleuze and Guattari's contrasting of rhizomes and treelike structures (rhizomes et racines) in Mille plateaux (1980) is crucial. Hardt and Negri's description of the world of global capitalism is also reminiscent of Castells' account of global networks based on the 'space of flows' rather than the 'space of places'.

The glocal. Although the term itself is relatively uncommon in academic writings (it seems to have caught on in the business world though), glocalisation (Robertson 1992) is a standard theme in nearly all anthropological writing about globalisation as well as most of the sociological and geographical literature. The argument goes like this. In real life, there exists no abstract, huge, global level of affairs on the one hand and local, lived realities on the other. The local level is in fact infused with influences from outside, be it culinary novelties or structural adjustment programmes; but these 'influences', on their part, have no autonomous existence outside their tangible manifestations. 'Microsoft' thus exists as a company based in Seattle, and also as the computer software used to run most personal computers in the world, but it does not exist as a global entity except as an abstraction of debatable value. It has numerous concrete manifestations, all of them local, and it offers a shared language, which makes transnational communication (and file exchange) possible, but as a global entity it exists only at the level of thought. Moreover, concepts describing impurity or mixing - hybridity, creolisation and so on - are specific instances of this general approach stressing the primacy of the local. The local-global dichotomy is, in other words, misleading.

Reflexivity and fluidity. Bauman's (2000) term 'liquid modernity' sums up this theoretical focus, which emphasises the uncertainty, risk and negotiability associated with phenomena as distinct as personal identification, economies and world climate in the 'global era'. That identities are not fixed and given once and for all is not exactly news any more, but it is widely held that the current 'post-traditional' (Giddens 1991) era is characterised by an unprecedented breadth of individual repertoires, forcing people to choose between alternatives and to define themselves in ways which were not necessary in earlier, less unstable and more clearly delineated social formations. Ambivalence and fundamentalism in the politics of identity are seen to stem simultaneously from this fundamental uncertainty.

Rights issues. While it has become unfashionable to defend cultural relativism as an ethical stance, opinion remains divided as to the legitimacy of group rights and, more generally, the relationship between group and individual in the contemporary 
world. Since the mere existence of groups cannot be taken for granted, the individual is often foregrounded. The debates may concern intellectual property rights, cultural and linguistic rights, as well as multicultural dilemmas such as the conflict between individualist agency and arranged marriages among non-European immigrants in North Atlantic societies.

The globalisation discourse tends to privilege flows over structures, rhizomes over roots, reflexivity over doxa, individual over group, flexibility over fixity, rights over duties, and freedom over security in its bid to highlight globalisation as something qualitatively new. While this kind of exercise is often necessary, it tends to become one-sided. Many anthropologists talk disparagingly about the jargon of 'globalbabble' or 'globalitarism' (Trouillot 2001), and tend to react against simplistic generalisations by reinserting (and reasserting) the uniqueness of the local, or glocal, as the case might be.

There is doubtless something qualitatively new about the compass, speed and reach of current transnational networks. Now, some globalisation theorists argue that the shrinking of the world will almost inevitably lead to a new value orientation, some indeed heralding the coming of a new, postmodern kind of person (e.g. Sennett 1998). These writers, who predict the emergence of a new set of uprooted, deterritorialised values and fragmented identities, are often accused of generalising from their own European middle-class habitus, the 'class consciousness of frequent travellers' (Calhoun 2002). The sociologist John Urry, lending himself easily to this criticism, argues in Global Complexity (2003) that globalisation has the potential of stimulating widespread cosmopolitanism - however, he does not say among whom. At the same time, Urry readily admits that the principles of closeness and distance still hold, for example in viewing patterns on television, where a global trend consists in viewers' preferences for locally produced programmes.

The newness of the contemporary world was described by Castells in 1998, in his trilogy The Information Society, where - after offering a smorgasbord of new phenomena, from real-time global financial markets to the spread of human rights ideas - he notes that what is new and what is not does not really matter; his point is that this is our world, and therefore we should study it. However much I appreciate Castells, I disagree. It does matter what is new and what isn't, if we are going to make sense of the contemporary world.

\section{Newness and the Old}

There is simultaneously something very new and something very old about the contemporary world. John Gray, in his essay on the al-Qaeda and what it means to be modern (Gray 2003: 119), argues that 'it is the interaction of expanding scientific knowledge with unchanging human needs that will determine the future of our species'.

Put differently, shifting circumstances influence any narrative trying to make sense of the world. The growth of science and technology creates new frameworks for the enactment of human projects, which nevertheless remain rooted in the fundamental human experiences of community and alienation, security and individuality. Perhaps nowhere is this tension more evident than in the politics of culture and identity in the world of the early $21^{\text {st }}$ century, which, incidentally, may be dated to 11 September 2001 or to 1991. I am inclined to put my money on 1991, for the following reasons. 
First of all, 1991 was the year when the Cold War was called off once and for all. The two-bloc system that had defined the postwar era was suddenly gone. The ideological conflict between socialism and capitalism seemed to have been replaced with the triumphant sound of one hand clapping. By 1991, it was also clear that apartheid was about to go; Mandela had been released from prison the year before, and negotiations between the Nationalist Party and the ANC had begun in earnest.

Secondly, Yugoslavia began to dismantle itself with surprising violence, fed by a kind of nationalistic sentiment many believed to have been overcome. Around the same time, the Hindu nationalists of the BJP (Bharatiya Janata Party, Indian People's Party) went from strength to strength in India. The identity politics of the state, or of statelike bodies, was thus not something of the past. In other words, openness and closure were still twin features of politics, but they were operating along new lines.

Thirdly, 1991 was the year in which the Internet began to be marketed to ordinary consumers, so that Mr and Mrs Smith could walk into the shop and buy their subscription to America Online. This was new, just as new as the pocket-sized mobile phones which all of a sudden began to spread across the world, from Mauritius to Iceland, around 1991. Deregulation of markets had taken place in the preceding decade, but many of the effects of a weaker state and a less manageable and predictable market were being felt only now, helped by new information and communication technology.

\section{Overheating}

This post-1991 world is also one of intensified tensions and frictions. We need only count the present number of transatlantic flights or the number of transpacific telephone connections to realise that the webs of connectedness are hotter, faster and denser than in any previous period, with repercussions virtually everywhere. The growth of urban slums throughout the Third World is an indirect result of economic globalisation (Davis 2006), just as the relative disconnectedness from the Internet in Africa - bracket South Africa, and there are more Austrians than Africans online - is a significant fact alongside the growth in text messages in China, from nil to eighteen billion a month in less than ten years. The networked capitalist world, in a word, is a framework, or scaffolding, for almost any serious inquiry into cultural and social dynamics.

This is an accelerated world, where everything from communication to warfare and industrial production takes place faster and more comprehensively than ever before. In physics, speed is just another way of talking about heat. Thus, when you say of someone that he or she is suffering from burnout, the metaphor is an apt one. The burnout is a direct consequence of too much speed.

This could be a main reason why the notion of global warming has caught on in such a powerful way in the North Atlantic middle classes. The risk of global warming may be real, but that is not the point: By focusing on literal heat as an unintentional consequence of modernity, the narratives about global warming fit perfectly with, enrich and supplement, the other narratives about the contemporary age. They function as a natural-science corollary of stories about terrorism and imperialism, roughly in the same way as chaos theory, in the 1980s, seemed the perfect natural-science companion for postmodernism in the humanities. All these narratives, and their relations, depict the contemporary world as one 'out of control', fraught with alienation, powerlessness, 
global forces and injustices brought about, and reproduced, by the rich and powerful - yet they are, without knowing it, digging their own grave. Above all, the notion of global warming feeds into a larger and more enduring story about acceleration, which, in a sense, is the story about modernity as such.

In a world of increased speed, intensified contact across boundaries and, as a result, the incessant questioning of these very boundaries, a sense not only of vulnerability but of instability and uncertainty is very widespread. New zones of tension graft themselves onto the old and perhaps universal lines of conflict - power versus powerlessness, wealth versus poverty, autonomy versus dependence, recognition versus humiliation. Some of these emergent conflicts, which will probably define the present century, are:

- Globalisation versus alterglobalisation - the new social movements looking for viable, locally based alternatives to the TINA doctrine ('There Is No Alternative');

- Environmentalism versus development - saving the planet is posited as a threat to development, especially in the Third World;

- Cosmopolitanism versus identity politics (including xenophobia and religious fundamentalism) - a main dimension of politics almost everywhere in the world now, frequently supplanting the left/right divide;

- Inclusion versus exclusion - walls, physical and metaphorical, preventing the free movement of people and their full inclusion in society;

- Uniformity versus diversity - shared templates of modernity articulating with local specificity; and finally

- Cultural autonomy versus the quest for recognition - finding the balance, as LéviStrauss once put it, between contact and isolation.

It is clear that the heightened speed with which encounters take place implies an unprecedented need for traffic rules. Movement has to be channeled. Laws regulating immigration and citizenship are obvious examples, but so are attempts - in some countries - to keep the language free of contamination from foreign (often English) influence and purification attempts taking place in some religious groups, such as the Deobandi movement in Pakistan seeking to purge Pakistani Islam of Hindu elements. Purity is pitted against filth, order against chaos. A desperate need of tidiness in a messy world is making itself felt everywhere, albeit in different ways.

Amidst this flurry of contradicting claims, cultural change and hotly disputed identities, boundary work is more often frantic than calm: Who is inside and outside the group, what are the criteria for being an insider, and what does it mean to be an individual with proper, socially recognised credentials and personal integrity? I begin this exploration with an examination of one of the most intriguing and shocking characters of the classic modern literature.

\section{Fluid Identities}

Henrik Ibsen's plays from the latter half of the nineteenth century are widely admired for their psychological depth and their accurate depiction of contradictions in the bourgeois family of late-nineteenth century Europe. However, in some important ways, his 
earlier plays Brand and Peer Gynt (Ibsen 1972 [1867-1868]) speak more directly to the sensibilities of the early $21^{\text {st }}$ century than the dramas dealing with late-19th century bourgeois society. Brand was a play about a Christian fundamentalist despairing at the moral decay and confusion he saw all around him, and his attempts to bracket off his own existence and that of his flock of faithful, from the surrounding turmoil. His attempt to escape from modernity intended to create a controlled space where all questions could be answered, a community which was predictable and morally consistent.

Brand seeks purity and simplicity. By contrast, the protagonist of Ibsen's next play, Peer Gynt, is an entrepreneur and an adventurer who lies and cheats his way across the world, who makes a small fortune in the, by then illicit, slave trade, who poses as a prophet in North Africa and as a cosmopolitan gentleman on a Mediterranean coast, before returning to his native mountain valley only to discover that his personality lacks a core. The struggles involving collective identification in the contemporary era, with which much of my research for nearly twenty years has incidentally been concerned, revolve around the questions raised by Ibsen in the $1860 \mathrm{~s}$.

The two characters cover, between them, the span between fundamentalism and collectivism on the one hand, and ambivalence and individualism on the other. Brand stands for destiny and security, while Peer stands for freedom and insecurity. The contrast between the two is part and parcel of the experience of the children of immigrants in Western Europe, to mention just one contemporary parallel.

In order to begin to understand social belonging and identity, we first have to consider personhood. I realised this years ago while writing a book about identity politics (Eriksen 2004), discovering that I had not done the groundwork of studying the foundations of any kind of social identity, the person (cf. also Cohen 1994), and his or her forms of attachment, seen as the basis for security.

The Latin term persona originally meant mask, which indicates that personal identity is shifting and can be treacherous (cf. Mauss 1960). Life is a stage (Shakespeare), and personality is like an onion - layer upon layer, but with no core (Ibsen). When all the layers of makeup and make-believe are peeled away, do we then encounter the real person - or do we instead meet a faceless monster? The answer from social science is: neither. Even 'real persons' have to play out their realness through an identity which is recognisable to others. He or she must, for example, possess a linguistic identity. The phantasmagoric point zero, where the 'real person' coalesces with the faceless one, is tantamount to autism. There is no 'other person' behind the social person.

Personal identity is shaped through social experiences. Some of them are easily forgotten, some can be interpreted to fit a present state one wants to belong to (it is never too late to obtain a tragic history or a happy childhood if one needs it), some may be more or less fictional, and yet others cannot be modified at all. In this sense, personal biographies are reminiscent of national historiography and religious myths of origin. Personal experiences are as malleable as national histories, neither more nor less. They can attach us to a great number of different communities based on gender, class, place, political persuasion, literary taste, sexual orientation, national identity, religion and so on. Yet they cannot be bent indefinitely; certain facts about ourselves are unchangeable. One can deny them, but they keep returning - as the ageing Peer Gynt discovers in the final act. As Bob Marley once put it: 'You can't run away from yourself'. 
Peer tries to do just this, and he thus sacrifices security for the sake of freedom; Brand does the opposite. A parallel to the contrast between Peer Gynt and Brand is found in a metaphor used among some West African peoples. In describing what a person is, they compare it with a tortoise. It may stick its head out, making itself visible and vulnerable, but it then retracts its head into the shell, rendering itself hidden and invincible. This metaphor seems to travel well into the world of mass media and reality TV. Some of our contemporary tortoises prefer to stay inside their shells most of the time, while others live almost continuously with their heads stuck out for all to see.

What the tortoise metaphor does not claim, is that there exists an insulated, pure self in the inner recesses of the individual, which is independent of its surroundings. Such a creature is difficult to envision. For example, we depend on thinking through linguistic categories, and even if we usually keep our thoughts to ourselves, at least we share them with a few confidantes. The metaphor of the tortoise, transposed to contemporary modern societies, is best understood as stating that human beings switch between being socially extroverted and directed towards the open, uncertain external world, and being socially introverted, limited to that which is secure and familiar. It deals not so much with the internal life of the individual as with two forms of sociality; the secure and the insecure, the closed and the open.

\section{The Meaning of 'We'}

Secure sociality moves in a sphere of undisputed we-feeling, a realm where one may be backstage, speak one's dialect, laugh at in-jokes, savour the smells of one's childhood and know that one has an intuitive, embodied cultural competence successfully performed without even trying. In a field of secure sociality, everyone is predictable to each other, and if not, there are ways of demarcating displeasure which are immediately understood by others. A relaxed intimacy engulfs secure sociality.

Insecure sociality is to a much greater extent characterised by improvisation and negotiations over situational definitions. Whoever meet in this kind of field are much less secure as to whom they are dealing with, and as a result, less certain as to whom they are looking at in the mirror. The opportunities are more varied and more open to a person in a state of insecure sociality than to someone subject to the predictable routines of secure sociality, but the risks are also much greater.

Insecure sociality appears, typically, in cosmopolitan cities, along trade routes and - especially after the industrial revolution - in societies undergoing rapid change. Suddenly, something new happens, and one finds oneself in a setting with no preordained script to be followed. One is faced with the task of rebuilding the ship at sea.

A typical reaction to this kind of insecurity is withdrawal, but it is equally common to try to redefine the situation to make it resemble something familiar. The work amounting to making insecure situations secure takes many shapes. Imperialist powers may try to reshape their new lands to make them less threateningly different, or they erect physical boundaries against the aliens, as the architects of apartheid did in South Africa and Israel is doing presently. Dominated peoples may try to imitate their rulers in order to impose stability on their world, or they may create new boundaries fencing off their lives through separatism, revolution or independence. 
Is insecurity a good or a bad thing? That depends. In social anthropological theory, different terms are being used, which provide different answers to the question. Mary Douglas (1966), who belongs to a tradition focusing on the study of social integration and assuming it to be a good thing, regards departures from the existing order as anomalies. They are cumbersome since they do not fit in. People who appear as anomalies become anomic, or normless -alienated, confused and unhappy. In Douglas' great intellectual mentor Durkheim's view, anomie was an important cause of suicide.

An opposite approach is found in the early work of Fredrik Barth (1963), who, in the early 1960s, directed a research programme about the entrepreneur in Northern Norway. According to Barth's definition, the entrepreneur was someone who bridged formerly discrete spheres; who found new commodities to sell in new locations, new ways of running a business, new niches and so on. He thrived on uncertainty and change, building his empire in the interstices. In his purest form, Barth's entrepreneur was a Peer Gynt; poorly integrated into the moral community, but hardly a candidate for suicide. It may perhaps be said that the entrepreneur fares like everybody else in the age of neoliberalism, which values freedom so highly but neglects security. Whenever one has success, the range of options and the scope of personal freedom feel fantastic, but the moment one hits the wall, freedom is reinterpreted as insecurity and the choices as a kind of coercive compulsion. The entrepreneur becomes an anomaly the moment he fails to succeed.

It is well documented that identification in our day and age can be an insecure kind of task with many difficulties and poor predictability. People who formerly had no mutual contact are brought together, new cultural forms arise, and the dominant ideology dictating that life should consist in free choices puts pressure on everyone. Good old recipes for the good life are conventionally discarded as reactionary and inhibiting. The result may just as well be frustrated confusion as positive self-realisation.

Even without the aid of this kind of freedom ideology, capitalism is capable of creating insecurity and new social dynamics. It has been a massive force, uprooting people from their conventional ways of doing things, moving them physically, giving them new tasks and bringing them into contact with new others. Innovative ways of dealing with difference may thereby emerge. For example, when mining began in the copper-rich areas of the eastern parts of present-day Zambia in the 1920s, tribals were turned into urban workers overnight. They spoke many languages and had different customs and kinship systems, but they soon began to classify each other, in a rough and ready way, on the basis of ideas about social distance. The people hailing from the western regions were seen as a category apart, likewise the Lozi speakers, the matrilineal peoples and so on. Some of the groups had experienced regular contact before urbanisation, and had conventionalised ways of dealing with each other. Many developed institutionalised joking relationships with each other, easing the tension of intercultural contact through humour. (This wonderful African institution deserves being exported elsewhere. Perhaps Jews and Palestinians, or Christians and Muslims, might want to give it a try?)

\section{Recognition as a Scarce Resource}

In his memoir from the 20th century, Todorov (2001), describes three dangers facing the post-totalitarian world. One is instrumentalisation of social relations - typically expressed as unfettered market liberalism, or rather, a loss of the social principles of 
solidarity and decency, which prevented markets from expanding outside the economy strictly speaking, and which also curtailed the power of state bureaucracies in liberal societies. These anxieties are neither uncommon nor new. Similar concerns with bureaucracies were expressed by the inventor of the theory of modern bureaucracy, Max Weber, and worries about the expansion of the market principle were voiced by Habermas in the 1960s, Lukács in the 1920s, and Marx in the 1850s. The second danger is moral correctness - sanctimonious and authoritarian conformism, in Europe typically expressed through the recently implemented bans on smoking in public places. The third danger identified by Todorov is the topic of the present discussion: Fragmenting identity politics, where universal values are bracketed in the name of group self-determination, where commitment to shared societal projects is weakened, and where open conflict between identity based groups may easily flare up - not so much because they are culturally different, but because they have few interests in common. This is a vision of a classic plural society without a colonial ruling class.

I share all his anxieties, and might have wanted to add one or two of my own. Yet there can be no easy way out. The only credible responses to the challenges facing humanity have to be ambivalent, doubtful, cautious, with instincts favouring pluralism and a multiplicity of voices rather than universal recipes for happiness. It is, in other words, the openmindedness of the Renaissance and the optimistic view of human nature of the Enlightenment we need to carry with us in this new, old world. Given that neither the USA of the Bush II era (2001-2008) nor its adversaries, real or imagined, are easily given to ambivalence, it is an ironic fact that two of the most influential ideological thinkers of the American right -authors of widely distributed books about the 'new world order', and keenly listened to in circles near the White House- are both partly correct, although they seem to be saying opposite things. They are also wrong in crucial respects. Francis Fukuyama (1992) (in)famously argued that Western democracy is the only game in town worthy of the name, and that global politics nowadays simply consists in attempts, by the less unfortunate nations, to achieve the same levels of consumption and liberal rights as those enjoyed by Americans. In this context, he also argues that the quest for recognition is fundamental and accounts for various forms of identity politics. The late Samuel Huntington (1996), on the other hand, has argued that current and future conflicts will take place not between ideologies, but between 'civilizations', that is, related clusters of cultures, such as the West, Islam, Hinduism and Eastern Christianity. Both Fukuyama and Huntington have been severely criticised by academics and other intellectuals, and rather than repeat all the criticisms, I would argue that they are both partly right. Fukuyama is right to assume that recognition by others is a notoriously scarce resource in the contemporary world, but he is wrong in believing that recognition can only be achieved through the successful adoption of Western values and ways of life. Huntington is correct in saying that cultural differences are important, but he is hopelessly off the mark when he tries to map out those differences - his concept of civilizations is theoretically inconsistent and empirically misleading - and there is no reason to assume that such differences necessarily lead to conflict. In fact, it has been argued that none of the armed conflicts of the 1990s were in line with Huntington's predictions (Fox 2000).

We must nonetheless concede that these conservative American thinkers correctly claim that recognition and respect are important, and that cultural differences matter 
in politics. Now, where does this lead us? Apparently, in the general direction of postcolonial theory.

According to writers like Frantz Fanon, Ngugi wa Thiong'o and Edward Said, the most difficult form of decolonisation consists in purging the mind of imperial categories and prejudices (Ngugi 1985); in developing a self, and an identity, and a self-consciousness which is not confined to the frame of mind imposed by the colonisers. In giving the people of the world the choice of being either with the US or with the terrorists, Bush II refused to acknowledge any position developed out of other concerns than the US-al-Qaeda axis. This attitude is the opposite of a cosmopolitan vision based on trust and the laws of gift exchange, and has had repercussions in many parts of our societies, from the idiotic and humiliating security checks in airports to earnest debates about the possible incompatibility of Islam and democracy. The postcolonial view, by contrast, insists on equality and mutual respect across differences.

In the context of the $21^{\text {st }}$ century global security crisis involving US global military hegemony and violent reactions often based on the politics of identity (a situation which has deep structural dimensions and did therefore not end with the election of Barack Husain Obama in 2008), this starting-point implies certain preliminary conclusions: Effective human rights activism requires at least a minimal knowledge about local contexts and, particularly, about local conflicts. For poor countries to give wholehearted support to notions of the inalienable rights of the individual, more is required than decisions to cut aid to countries which are not yet committed to a free press and multi-party parliamentary democracy. What is needed are social reforms which give people increased control over their own existence - land reforms, job opportunities, accountable state institutions and so on, in order to be able to engage in symmetrical relationships with others in situations of work as well as play. As an implication, a global policy is needed where both big power (state, geopolitics) and small power (family, community) are more equitably distributed.

This struggle, moreover, is as much about the means of communication as about the means of production. As the Algerian author Rachid Mimouni put it, what ought to be required of the Europeans is 'an attempt to understand rather than material aid. What can democracy mean in a country like Ethiopia, where dozens die of starvation every day?' (Mimouni 1992: 156). There are, in other words, serious problems which are not solved by a formulaic introduction of human rights, and there are people who for perfectly understandable reasons see talk about the freedom of expression as a diversion from the real issues. One may by all means argue that Muslim men should give their wives the same rights and opportunities as, say, Scandinavian women have, but it would be silly to assume that they think in the same way as we do. If one does so-promoting human rights with the subtlety of a bulldozer - one implicitly says, as missionaries and foreign aid aristocrats have done for years, that the experiences of others have no value, and that the others had better become like ourselves before we bother to listen to them. They are obliged to accepting our gift, but there is no reciprocal obligation applying to ourselves. In effect, one says that they do not exist until they have become similar to ourselves. Respecting other life-worlds is, it must be emphasised, not the same as ethical relativism, but on the contrary a recognition of the need for a dialogue to go both ways, since the alternative is monologue or worse: the sound from one hand clapping. 


\section{Towards a Cosmopolitan Frame of Discourse}

In the misty dawn of time, when the world was still young and fathomable for the common people - say, 20 to 25 years ago - not only was it seemingly possible to understand global politics, one could also easily divide the world into discrete cultural regions the world simply seemed to be a composite of cultures. Thus, in Denmark they spoke Danish, and the Danes were liberal Protestants with characteristic Danish features, a characteristic body language, and a love for red sausages and pilsner beer; in Bangladesh the Bengali Muslims had their own customs and traditions; all the tribes in Kenya had their particular, unique cultures and languages, and so on. According to the prevailing worldview at that time there was not much contact between these cultures, although there was some exchange and mutual influence going on between them. Cultural contact, which developed through missionary work, aid, migration and the diffusion of modern institutions such as the modern nation state and the capitalist labour market, gave rise to a set of problems related to the encounter of separate cultures, each with its own special, internal logic. Often the results were misunderstandings and conflicts, and fairly often the stronger culture came to dominate the weaker. This was often referred to as cultural imperialism - a term which is today rarely used, though it was common in intellectual discourse a surprisingly short time ago.

This understanding of culture and cultural differences, which has been fundamental to European thinking ever since Romanticism and crucial both in nationalist ideologies as well as in cultural anthropological method, today, all of a sudden, appears old-fashioned and dated. Such change partly relates to a change in our way of thinking; however, far more important is the fact that the world has changed. Although cultures never have been completely isolated and without contact with other cultures, and despite the fact that cultural isolation often has been exaggerated both by scholars and by others, the possibility of cultural isolation shrinks day by day. Both economy and politics have become globalised - that is, to an increasing extent processes affect people in different places at the same time as they cannot necessarily be traced back to one specific place. Because of advancements in communication technology, money, goods, people, ideas, and power travel across the world with little friction and at a high speed. There has been an enormous growth in air traffic during the past 60 years, and airline fares continue to drop. Satellite television, the Internet and related technologies have accelerated the development of a world without delays, where certain events can take place in all places at the same time and where distances are shrinking rapidly.

At the same time, the huge contrasts in life opportunities across countries and regions create an unstable situation and make it advantageous for some people from poorer countries to move permanently or temporarily to rich countries. This is visible even in geographically peripheral regions such as Scandinavia, and questions concerning immigrants and integration are a recurrent issue in Scandinavian public debate.

Needless to say, changes of this magnitude will have consequences on a cultural level and consequently demand new ways of communicating across cultural differences. Some believe that the processes of globalisation will lead to the annihilation of cultural differences and that human beings throughout the world are becoming more and more alike. This view is shared by both optimists such as Fukuyama, who hopes that the entire world will become politically and economically similar to the USA, and by pessimists like Lévi-Strauss, who was for seventy years convinced that the great cultural diversity 
of the planet was about to be lost. A different perspective, common among intellectuals in poor countries, focuses on the neo-colonial aspects of globalisation; how economic differences are sustained, and how the seemingly boundless openness that has characterised the era of globalisation also has delimiting and marginalising effects.

A third approach involves the new forms of cultural variation that are evolving in the context of global modernity, because modernity does not equal cultural homogeneity. The globalisation of culture does not create global people. But globalisation creates 'cultural creoles', people who live at the intersection of different cultural traditions, constantly bombarded with impulses, expectations, demands, and opportunities from several different angles, and who continuously create themselves, not from ready-made prescriptions but by crafting their own unique, complex cultural fabric (Hannerz 1990; see also Stewart 2007).

The old map reveals a world of cultural islands. On each island people have their special way of living, with their own traditions and so forth, but there is relatively little contact between the islands. It is extremely difficult to navigate the world of today using such a map. That is a main reason that a significant part of the intellectual community has been at work revising that map for some time. (Naturally, it is also possible to change the territory so that it matches the old map - a solution which might take the form of ethnic cleansing.) This revision process is evident in the bifurcation of history into different narratives - stories or histories. New nuances and a new diversity are incorporated into the conception of national identities, and new groups of people attain a sense of subjective and objective belonging to their society. Rebuilding the ship at sea has become a necessary task.

A kind of competence necessary for this task to be successful is the ability to listen, a resource in notoriously short supply in the contemporary world. A cosmopolitan ethics may be a starting point, one contributing simultaneously to decolonising the minds of previously colonised peoples, and to bridging the gaps of intercultural relations through forms of communication where the symbolic power has been decentralised.

In a review of Appiah's Cosmopolitanism (Appiah 2006), John Gray states that 'As a position in ethical theory, cosmopolitanism is distinct from relativism and universalism. It affirms the possibility of mutual understanding between adherents to different moralities but without holding out the promise of any ultimate consensus.' (Gray 2006)

In other words, fervent missionary activity is not, according to this view, compatible with a cosmopolitan outlook, nor is an ethical position which assumes that there is but one good life. These two initial principles are, incidentally, in line with Kant's view of cosmopolitanism, which consistently emphasises the need to communicate across cultural and political boundaries, to accept hospitality when offered, and to respect the difference of the other without succumbing to relativist confusion.

In this kind of world, irreducibly diverse and chronically overheated, we are all strangers in a strange land. At the same time, we are all in the same boat, divided by a shared destiny.

\section{References}

Appiah, Kwame Anthony (2006) Cosmopolitanism: Ethics in a World of Strangers. New York: Norton. Barth, Fredrik, ed. (1963) The role of the entrepreneur in social change in northern Norway. Bergen: Universitetsforlaget. 
Bauman, Zygmunt (2000) Liquid Modernity. Cambridge: Polity.

Calhoun, Craig (2002) 'The class consciousness of frequent travellers: Towards a critique of actually existing cosmopolitanism'. In Conceiving Cosmopolitanism: Theory, Context and Practice, eds. S. Vertovec and R. Cohen, pp. 86-109. Oxford: Oxford University Press.

Castells, Manuel (1996) The Rise of the Network Society. Oxford: Blackwell.

Castells, Manuel (1998) End of Millennium. Oxford: Blackwell.

Castles, Stephen and Alasdair Davidson (2000) Citizenship and Migration: Globalization and the Politics of Belonging. London: Palgrave Macmillan.

Cohen, A.P. (1994) Self Consciousness. London: Routledge.

Douglas, Mary (1966) Purity and danger: An analysis of concepts of pollution and taboo. London: Routledge and Kegan Paul.

Eriksen, Thomas Hylland (2001) Bak fiendebildet: Politisk islam og verden etter 11. september (Behind the enemy image: Political Islam and the world after 9-11). Oslo: Cappelen.

Eriksen, Thomas Hylland (2004) Røtter og føtter: Identitet $i$ en omskiftelig tid (Roots and boots: Identity at a crossroads). Oslo: Aschehoug.

Eriksen, Thomas Hylland (2007) Globalization: The Key Concepts. Oxford: Berg.

Fukuyama, Francis (1992) The End of History and the Last Man. New York: Avon.

Giddens, Anthony (1991) Modernity and Self-Identity. Cambridge: Polity.

Gray, John (2006) 'Easier said than done'. The Nation, 30 January 2006.

Hannerz, Ulf (1990) 'Cosmopolitans and locals in world culture'. In Global Culture. Nationalism, Globalization and Modernity, ed. Mike Featherstone, pp. 237-52. London: Sage.

Hannerz, Ulf (1996) Transnational Connections. London: Routledge.

Hardt, Michael and Antonio Negri (2000) Empire. Cambridge, Mass.: Harvard University Press.

Harvey, David (1989) The condition of postmodernity. Oxford: Blackwell.

Huntington, Samuel (1996) The Clash of Civilizations and the Remaking of a World Order. New York: Simon and Schuster.

Ibsen, Henrik (1972) Oxford Ibsen: 'Brand' and 'Peer Gynt'. Oxford: Oxford University Press.

Maalouf, Amin (2001) Les identités meurtrières. Paris: Livres de poche.

Mauss, Marcel (1960) Sociologie et anthropologie. Paris: PUF.

Mimouni, Rachid (1992) De la barbarie en général et de l $\square$ intégrisme en particulier. Paris: Le pré aux clercs.

Robertson, Roland (1992) Globalization. London: Sage.

Stewart, Charles, ed. (2007) Creolization: History, Ethnography, Theory. Walnut Creek, Calif.: Left Coast Press.

Todorov, Tzvetan (1989) The conquest of America: The question of the Other. Oklahoma: Oklahoma University Press.

Todorov, Tzvetan (2000) Mémoire du mal, tentation du bien. Paris: Robert Laffont.

Trouillot, Michel-Rolph (2001) 'Close encounters of the deceptive kind'. Current Anthropology 42: 125-138. Urry, John (2003) Global Complexity. Cambridge: Polity.

Waters, Malcolm (2001) Globalization, 2nd edition. London: Routledge.

Zizek, Slavoj (2003) Organs without Bodies: On Deleuze and Consequences. London: Routledge. 